\title{
Removal of Antibiotics from Real Hospital Wastewater by Cold Plasma Technique
}

\author{
Phuong Thi Thanh Nguyen $\left(\mathbb{D},{ }^{1,2}\right.$ Hieu Trung Nguyen $\left(\mathbb{D},{ }^{3}\right.$ Uyen Nhat Phuoc Tran, ${ }^{2}$ \\ and Ha Manh Bui $\mathbb{D}^{4}$ \\ ${ }^{1}$ Institute for Environment and Resources, Vietnam National University, Ho Chi Minh 700000, Vietnam \\ ${ }^{2}$ Institute of Biotechnology, Vanhien University, Ho Chi Minh 700000, Vietnam \\ ${ }^{3}$ Institute of Applied Technology, Thu Dau Mot University, Thu Dau Mot 750000, Binh Duong, Vietnam \\ ${ }^{4}$ Institute of Environmental Sciences, Nguyen Tat Thanh University, Ho Chi Minh 700000, Vietnam
}

Correspondence should be addressed to Ha Manh Bui; manhhakg@yahoo.com.vn

Received 18 March 2021; Accepted 3 May 2021; Published 20 May 2021

Academic Editor: Abdullah Aldawsari

Copyright (c) 2021 Phuong Thi Thanh Nguyen et al. This is an open access article distributed under the Creative Commons Attribution License, which permits unrestricted use, distribution, and reproduction in any medium, provided the original work is properly cited.

\begin{abstract}
Hospital wastewater contains a complex mixture of bioactive substances and microorganisms that are deleterious to humans and aquatic animals. In this study, four antibiotics, namely, ofloxacin, ciprofloxacin, cefuroxime, and amoxicillin, respectively, from the wastewater of seven hospitals in Ho Chi Minh City, Vietnam, were monitored. The results revealed that the wastewater from these hospitals is contaminated with at least one of the antibiotics. In addition, the degradation capacity of the antibiotics by the wastewater treatment plant at one of the hospitals by the cold plasma technique was investigated. Furthermore, effects of the variation in $\mathrm{pH}$, interelectrode distance, applied voltage, and reaction time on the removal efficiency were investigated in terms of the reduction in antibiotics concentration, COD, and ammonia. Ciprofloxacin, cefuroxime, COD, and ammonia were almost eliminated, while ofloxacin and amoxicillin were reduced by more than $72 \%$ under optimum conditions (initial $\mathrm{pH}$ of 10 , reaction time of $15 \mathrm{~min}$, applied voltage of $30 \mathrm{kV}$, and interelectrode distance of $10 \mathrm{~mm}$ ). All of these factors affected the removal efficiency. The removal efficiency was most robust in the first $5 \mathrm{~min}$, and it increased with the increase in the reaction time. However, the removal efficiency tended to saturate over time, while it decreased with the increase in the reaction time. With an applied voltage of $30 \mathrm{kV}$ onwards, the removal efficiency was not significantly different. Most of the pollutants were predominately eliminated under slightly alkaline conditions ( $\mathrm{pH}$ of $\sim 10$ ). In addition, primary oxidants in the aqueous phase, such as $\mathrm{O}_{3}, \mathrm{H}_{2} \mathrm{O}_{2}$, and $\cdot \mathrm{OH}$, were generated. Besides, the obtained results also revealed that the decomposition of ciprofloxacin and cefuroxime follows the first-order reaction kinetics; meanwhile, the third-order reaction kinetics was most likely for the decomposition of ofloxacin and amoxicillin.
\end{abstract}

\section{Introduction}

As one of the sources of waste, hospital wastewater (HWW), which contains a high concentration of detergents, disinfectants, hormones, and even antibiotic compounds, causes severe environmental pollution. The presence of these compounds in HWW poses an adverse threat to living organisms. Several studies have reported that these antibiotics and their residues pose a substantial toxic risk to aquatic organisms [1]. Moreover, antibiotic residues can accelerate the production of antibiotic-resistant bacteria and antibiotic-resistant genes even at low concentrations, which could be a major threat to public health globally $[2,3]$. Extensive studies have reported that antibiotic compounds originating from HWW can be transported to ponds, rivers, and wastewater treatment plants [4]. Therefore, these compounds must be eliminated before their discharge into sewage systems. Several methods have been developed to eliminate these compounds in HWW. Conventional processes such as coagulation, aerotank, and adsorption have been applied for the treatment of real HWW; however, these methods are not adequate to remove contaminants [5-7]. 
Some advanced oxidation processes (AOPs), including photocatalysis $[8,9]$, ozone treatment $[10]$, activated persulfate [11,12], electro-Fenton process [13], and an electronbeam process [14-16], have successfully mitigated the pollutants present in synthetic HWW; however, these AOPs exhibit practical limitations when used on an industrial scale.

Recently, the application of cold plasma-one of the AOPs-has attracted considerable attention for wastewater treatment due to its efficiency, less chemical requirements, and low sludge production [17]. Cold plasma has been employed for the degradation of recalcitrant pollutants in the wastewater generated from pesticide production [18], a slaughterhouse [19], textiles [20], and pharmaceuticals [21-24].

Under aqueous conditions, cold plasma typically generates strongly reactive free radicals or molecules in situ, such as hydroxyl radicals $(\cdot \mathrm{OH})$, hydrogen radicals $(\cdot \mathrm{H})$, hydrated electrons $\left(e^{-}\right)$, hydrogen peroxide $\left(\mathrm{H}_{2} \mathrm{O}_{2}\right)$, ozone $\left(\mathrm{O}_{3}\right)$, and even UV light [18] by the following process [25].

$$
\mathrm{H}_{2} \mathrm{O} \longrightarrow \text { Cold plasma } \cdot \mathrm{OH}+\mathrm{e}^{-}+\mathrm{H} \cdot+\mathrm{H}_{2} \mathrm{O}_{2}+\mathrm{H}_{3} \mathrm{O}^{+}+\mathrm{O}_{3}+\mathrm{UV}
$$

The as-formed powerful oxidants can decompose and mineralize organic pollutants into carbon dioxide and water. Some studies have reported that cold plasma is an efficient technology for the removal of antibiotics. Lou et al. [26] have reported that the use of only dielectric barrier discharge (DBD), a type of cold plasma, can degrade $>80 \%$ chloramphenicol in contaminated soil. Kim et al. [27] have employed a DBD system and reported the removal of 9 antibiotic compounds, namely, lincomycin, ciprofloxacin, enrofloxacin, chlortetracycline, oxytetracycline, sulfathiazole, sulfamethoxazole, sulfamethazine, and trimethoprim, respectively, from a synthesis solution, with removal efficiencies varying from $60 \%$ to $90 \%$. In addition, Sarangapani et al. have employed cold plasma for the high-efficiency mitigation of two widely used antibiotics (i. e., ofloxacin and ciprofloxacin, respectively) from water and meat effluents [21]. The results revealed that cold plasma successfully degrades the examined antibiotics and that plasma treatment considerably reduces the activity of both antibiotics. The authors indicated that the advantages of cold plasma treatment include the oxidation or reduction of pollutants into biodegradable compounds without environmental risks, and the method can be an effective, ecofriendly, and economically promising technology for the treatment of wastewater in practical applications. Although these techniques can reduce the organic compounds in aqueous solutions, studies on removing these contaminants from real HWW are not available.

In this study, contamination by four widely used antibiotics (such as ofloxacin, ciprofloxacin, cefuroxime, and amoxicillin, respectively) from the wastewater of seven hospital treatment plants in Vietnam was investigated. Next, the application of cold plasma to eliminate these pollutants from the wastewater of one representative hospital was investigated. Furthermore, the effects of four factors, i. e.,
$\mathrm{pH}$, interelectrode distance, voltage, and reaction time, respectively, were examined by reducing the antibiotic concentration, COD, and ammonia. To the best of our knowledge, this is the first study to discuss the application of cold plasma for the treatment of hospital wastewater in Vietnam.

\section{Methodology}

2.1. Wastewater and Chemicals. Wastewater was obtained from equalization tanks at seven hospital wastewater treatment plants (i. e., National Hospital of Odonto-Stomatology, Oncology Hospital, Thong Nhat Hospital, Hung Vuong Hospital, General Saigon Hospital, Binh Dan Hospital, and Gia Dinh Hospital, respectively) in Ho Chi Minh City, Vietnam (Figure S1). The wastewater was collected in glass containers and preserved at $4^{\circ} \mathrm{C}$ for treatment by cold plasma.

Analytical-grade standards of ofloxacin, ciprofloxacin, cefuroxime, and amoxicillin ( $>98 \%$ purity) were used. In addition, HPLC solvents, such as methanol, acetonitrile, ethyl acetate, ammonium hydroxide solution $\left(\mathrm{NH}_{4} \mathrm{OH}\right)$, acetic acid $(\mathrm{AcOH})$, formic acid $(\mathrm{HCOOH})$, and other chemicals were of analytical grade. The chemicals and solutions were kept in the dark and stored at $4^{\circ} \mathrm{C}$.

2.2. The Cold Plasma Reactor Model. Figure 1 shows the schematic of a plasma reactor model, including plumbing, a reaction chamber, sewage tanks, water pumps, gas pumps, flowmeters, pump control valves, and switches. A gas mass flow meter and controllers were used to introduce air into the reactor chamber. The height and volume of the reaction chamber were $30 \mathrm{~cm}$ and $1500 \mathrm{~mL}$, respectively, which was designed with one inlet and one outlet. The water inlet was placed $12 \mathrm{~cm}$ from the bottom, and water was allowed to flow from the bottom up-the volume of the reaction zone was $600 \mathrm{~mL}$. The experiment was designed with plasma electrodes, including two SUS304 stainless-steel electrodes and a pointed tip anode electrode submerged in water. A rectangular design $(30 \times 25 \times 3 \mathrm{~mm})$ on a perforated electrode plate with a diameter of $4 \mathrm{~mm}$ served as the negative electrode. The top of the reaction chamber was a threaded lock cap comprising an insulating plastic, which fixed two electrodes of the model. A rectangular box composed of acrylic plastic with a volume of $2000 \mathrm{~mL}$ served as the reservoir for the output effluent.

2.3. Experimental Design and Procedure. Plasma treatment experiments were conducted on the basis of the single-factor design, i. e., in every series of experiments; only one independent factor was varied, whereas all other factors were maintained constant. Table S1 shows the parameters and their value ranges with the following initial conditions: initial $\mathrm{pH}$ of 6.7 , the reaction time of $15 \mathrm{~min}$, the distance between two electrodes of $20 \mathrm{~mm}$, and applied voltage in the range of $15-35 \mathrm{kV}$ at constant antibiotic concentrations for the examination of the wastewater from the General Saigon hospital. A total of four series were conducted to evaluate all 


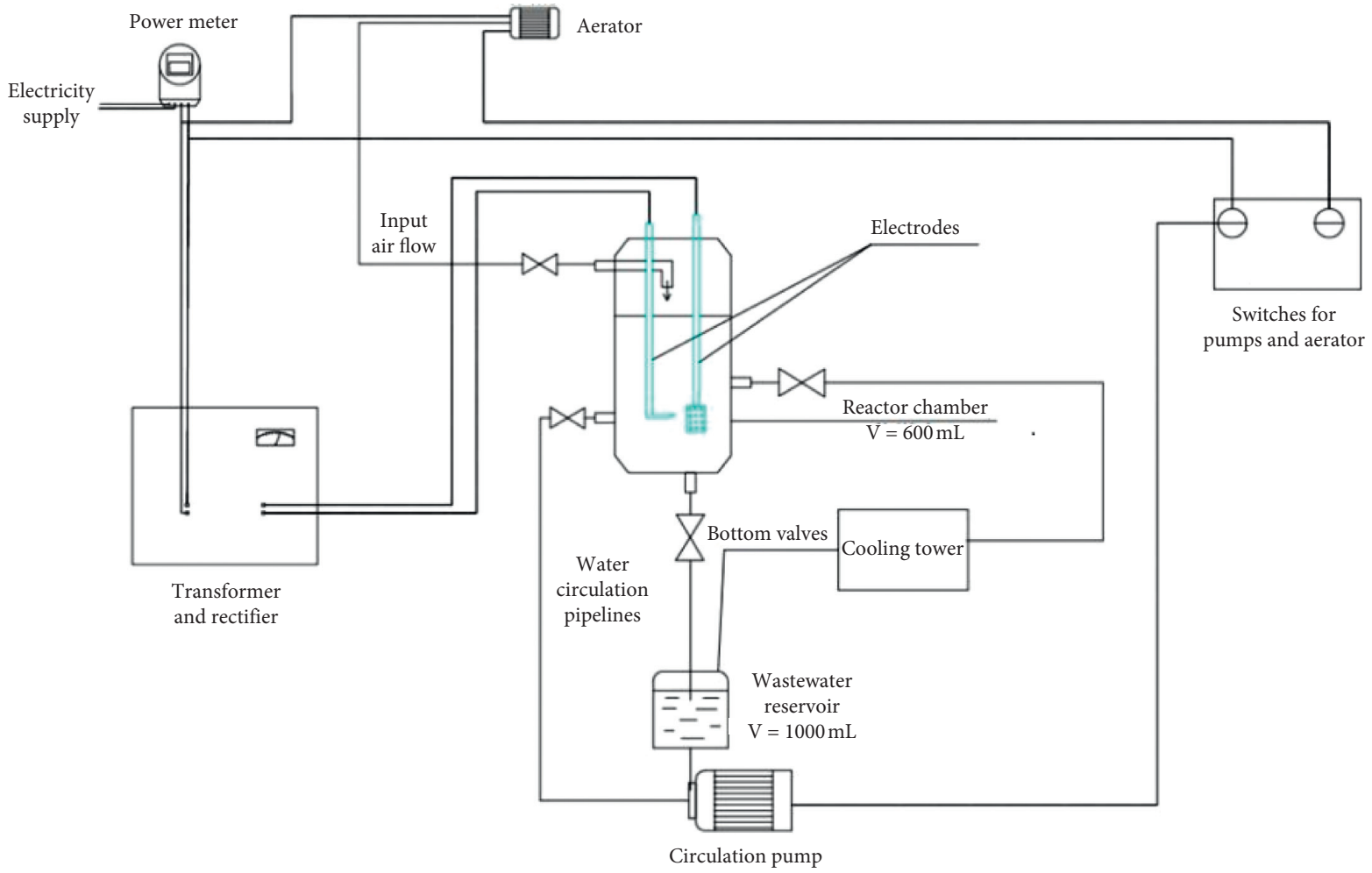

Figure 1: The cold plasma reactor chamber.

factors. Moreover, the formation of $\mathrm{O}_{3}, \mathrm{H}_{2} \mathrm{O}_{2}$, and $\cdot \mathrm{OH}$ were investigated by the variation in the $\mathrm{pH}$ and reaction time under optimum conditions (the distance between the two electrodes was $10 \mathrm{~mm}$, and the applied voltage was $30 \mathrm{kV}$ ).

In each run, $600 \mathrm{~mL}$ of the wastewater from General Saigon hospital (which was adjusted to the desired $\mathrm{pH}$ ) was added to the reaction chamber at the established gap between two electrodes, followed by locking the two valves at the bottom and the cooling tower. Then, the air was fed into the chamber at a constant flow rate of $4 \mathrm{~L} / \mathrm{min}$, the power supply was switched on, and the applied voltage was adjusted to the required values. After the desired reaction time, aliquots of the treated wastewater were sampled through the bottom discharge and analyzed.

2.4. Analysis Method. A Shimadzu HPLC system (Model 20AT) equipped with a UV detector was utilized to monitor the antibiotics extracted from the wastewater using solidphase microextraction method as follows. About $5 \mu \mathrm{L}$ of the analyte solution was injected into the HPLC valve using a $25 \mathrm{~mm}$ Puradisc syringe (sterile and free of endotoxins, $0.2 \mu \mathrm{m}$ PES Filter Media) and a Terumo syringe $(5 \mathrm{~mL})$ at room temperature $\left(25 \pm 2^{\circ} \mathrm{C}\right)$. The target analyzed compounds were separated on a Phenomenex Luna reverse phase $(\mathrm{RP}-18)$ column $(250 \mathrm{~mm} \times 4.6 \mathrm{~mm})$ packed with a C18 stationary phase having a particle size of $5 \mu \mathrm{m}$.

The pollution and pathogenic microorganism parameters in HWW before and after treatment, such as $\mathrm{pH}, \mathrm{COD}$, TSS, sulfide, ammonium, nitrate, phosphate, plant and animal fats and oils, coliforms, Salmonella, Shigella, and
Vibrio cholera, were analyzed according to the American Public Health Association [28]. Meanwhile, $\mathrm{O}_{3}, \mathrm{H}_{2} \mathrm{O}_{2}$, and . $\mathrm{OH}$ generated in wastewater also were determined by standard methods [28-30]. Results were expressed as the mean of triplicate measurements, and statistical analyses were performed using Microsoft Excel software release 2010 (Microsoft Corp., USA).

\section{Results and Discussion}

3.1. Characteristics of Hospital Wastewater. All of the HWW samples were contaminated with COD in the range from 191 to $539 \mathrm{mg} / \mathrm{L}$, while coliforms ranged from $1.5 \times 10^{5}$ to $1.4 \times 10^{7} \mathrm{CFU} / 100 \mathrm{~mL}$, and the other parameters were above the stipulated standards in some hospitals. Some antibiotics were detected in the wastewater; in particular, all four parameters were detected in the wastewater of the General Saigon hospital. These results revealed that contaminants are detected in most surveyed hospitals and are deleterious to residents (Table S2). Owing to the presence of all four contaminant antibiotics, the wastewater from the General Saigon hospital was selected for the plasma treatment experiment. The degradation efficiencies of the antibiotics from the hospital's wastewater treatment plant by the cold plasma technique were evaluated via the investigation of the effects of applied voltage, reaction time, $\mathrm{pH}$, and the interelectrode distance of the plasma reactor on the concentration of the four antibiotics in the effluents. In addition, the formation of oxidizing species, such as $\mathrm{O}_{3}, \mathrm{H}_{2} \mathrm{O}_{2}$, and. $\mathrm{OH}$, was investigated to clarify the degradation mechanism of cold plasma. 


\subsection{Plasma Treatment}

3.2.1. Effect of Applied Voltage. The effect of the applied voltage on the degradation of the antibiotics was investigated by conducting experiments at applied voltages of 15, 20, 25, 30 , and $35 \mathrm{kV}$ by maintaining the distance between two electrodes at $20 \mathrm{~mm}$ and the initial $\mathrm{pH}$ value at $\sim 6.7$ (background value of the General Saigon hospital wastewater) for a reaction time of $15 \mathrm{~min}$. With the increase in the applied voltage, the removal efficiency of antibiotics, COD, and ammonia by cold plasma treatment increased (Figure 2); however, the efficiencies were different for each antibiotic. Ciprofloxacin, cefuroxime, COD, and ammonia were mostly eliminated at an applied voltage of $\geq 25 \mathrm{kV}$, while no clear difference in the removal efficiency was observed with the further increase in the applied voltage to $35 \mathrm{kV}$ (Figures 2(b)-2(f)). The finding might be related to the low concentration of ciprofloxacin $(1.052 \mathrm{mg} / \mathrm{L})$ and cefuroxime $(0.273 \mathrm{mg} / \mathrm{L})$ and the facile oxidizing substances that contribute to the COD in the HWW sample. That is, an applied voltage of $25 \mathrm{kV}$ is adequate to release sufficient oxidants (. $\mathrm{OH}, \mathrm{O}_{3}$, and $\mathrm{H}_{2} \mathrm{O}_{2}$ ) for eliminating ciprofloxacin, cefuroxime, COD, and ammonia during the plasma process [31]. On the contrary, at an applied voltage of $35 \mathrm{kV}$, the highest removal efficiencies of $50.22 \%$ and $35.40 \%$ were observed for ofloxacin and amoxicillin, respectively (Figures 2(a) and $2(d))$. The highest applied voltage can be attributed to the generation of an increased number of reactive species at a higher applied voltage. However, the low removal efficiencies mentioned above may be explained by inadequate oxidant products for removing high concentrations of ofloxacin $(41.23 \mathrm{mg} / \mathrm{L})$ and amoxicillin $(23.58 \mathrm{mg} / \mathrm{L})$. The increase in the removal efficiency with an adequate increase in the applied voltage is consistent with the results reported by Sarangapani et al. [21]; in their study, the authors have reported that with the rise in the voltage from 70 to $80 \mathrm{kV}$, the plasma degradation efficiency increased from $75 \%$ to $89 \%$ for ciprofloxacin and from $88 \%$ to $92 \%$ for ofloxacin. Even at an applied voltage of $35 \mathrm{kV}$, the highest removal efficiency was observed for ofloxacin and amoxicillin; however, the difference in removal efficiencies was not significant between the applied voltages of $30 \mathrm{kV}$ and $35 \mathrm{kV}$. Moreover, to optimize the experimental conditions and reduce energy for plasma treatment (saving time and safety), an applied voltage of $30 \mathrm{kV}$ was selected for subsequent experiments.

3.2.2. Effect of Reaction Time. Experiments were conducted at reaction times of $5,10,15,20$, and 25 min with a distance between two electrodes of $20 \mathrm{~mm}$, an applied voltage of $30 \mathrm{kV}$, and a natural $\mathrm{pH}$ value (6.6). With the increase in the reaction time, the degradation efficiency increased (Figure 3); however, similar to the effect of the applied voltage, the results revealed that ciprofloxacin and cefuroxime are rapidly degraded in the first $10 \mathrm{~min}(>90 \%)$ and reach a plateau until the reaction is completed (Figures 3(b) and $3(c)$ ); this trend also was observed in the case of COD and ammonia at a reaction time of $15 \mathrm{~min}$ (Figures 3(e) and 3(f)).
This result is consistent with the following theory: the reaction time exhibited a positive effect on the degradation of organic compounds in the plasma process. With the increase in the reaction time, the disturbing process is strong, the reaction occurs rapidly, and organic substances are exposed to strong oxidizing substances [32]. However, with the increase in the reaction time to greater than $15 \mathrm{~min}$, the degradation efficiency remained stable. It is hypothesized that with the further increase in the reaction time, the number of intermediate products (between the formed oxidants and antibiotics) increases, which are competing with antibiotics; hence, the degradation efficiency decreases. Meanwhile, a different trend in degradation efficiencies was observed in the case of ofloxacin and amoxicillin (Figures 3(a) and 3(d)), where their efficiencies reached peak values at a reaction time of $30 \mathrm{~min}$. This might result in the presence of inadequate concentrations of oxidants (such as $\cdot \mathrm{OH}, \mathrm{O}_{3}$, and $\mathrm{H}_{2} \mathrm{O}_{2}$ ) to remove high concentrations of ofloxacin and amoxicillin from wastewater. This pattern of results is consistent with the previous study of Kim et al. [27], where plasma was used to degrade enrofloxacin in an aqueous solution. The author revealed that the decomposition of $1 \mathrm{mg} / \mathrm{L}$ of enrofloxacin could be completed only within $20 \mathrm{~min}$, while around $30 \mathrm{~min}$ is required to reduce the concentration of the same compound from $5 \mathrm{mg} / \mathrm{L}$ to $1 \mathrm{mg} / \mathrm{L}$. In terms of removal efficiency, a reaction time of $30 \mathrm{~min}$ was optimum for subsequent experiments. However, excluding ofloxacin and amoxicillin, all of the six parameters and coliforms (data not shown) were entirely eliminated during $15 \mathrm{~min}$. Furthermore, the shortened reaction time ensures savings in operational costs. Hence, a reaction time of $15 \mathrm{~min}$ reaction is selected for subsequent experiments.

3.2.3. Effect of the Initial $p H$. Effects of the initial $\mathrm{pH}$ on the removal of antibiotics by cold plasma were investigated in the range from 7 to 10 . The distance between the two electrodes and applied voltage was maintained constant at $20 \mathrm{~mm}$ and $30 \mathrm{kV}$, respectively, during a reaction time of $15 \mathrm{~min}$ for all experiments. With the increase in the initial $\mathrm{pH}$ from 7 to 10 , the overall removal efficiencies increased for all pollutants by cold plasma treatment (Figure 4). These results are in agreement with those reported in recent studies where an increase in the $\mathrm{pH}$ accelerates the formation of $\cdot \mathrm{OH}$ due to the decrease in the $\cdot \mathrm{OH}$ redox potential according to the Nernst equation $[33,34]$ :

$$
\mathbf{E}^{0}=E_{\mathrm{HO}^{*} / \mathrm{H}_{2} \mathbf{O}_{2}}^{0}-0.059 \mathbf{p H}
$$

In other words, the redox potential of $\cdot \mathrm{OH}$ might slightly decrease from 2.39 to 2.21 with the increase in the $\mathrm{pH}$ from 7 to 10 [33]. At a constant applied voltage, the decrease in the redox potential can enhance $\cdot \mathrm{OH}$ production; hence, the oxidant can react with an increased amount of pollutants in wastewater, leading to increased removal efficiencies. Panorel et al. [24] have reported that the oxidation efficiency of paracetamol under alkaline conditions $(52 \mathrm{~g} / \mathrm{kW} \cdot \mathrm{h})$ is substantially greater than that under acidic conditions $(28 \mathrm{~g} / \mathrm{kW} \cdot \mathrm{h})$. With the increase in the initial $\mathrm{pH}$, even the overall removal efficiencies of 


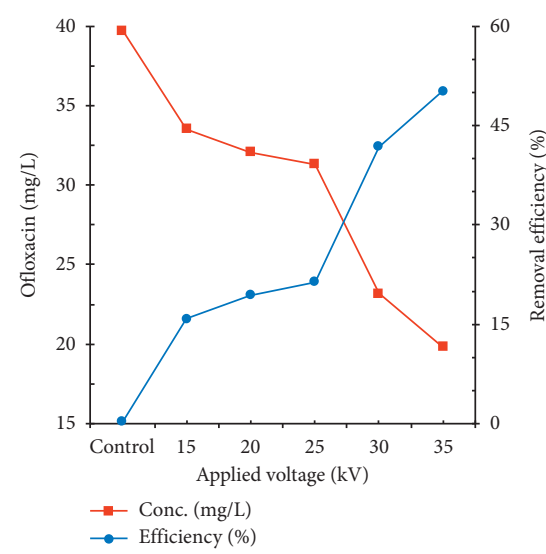

(a)

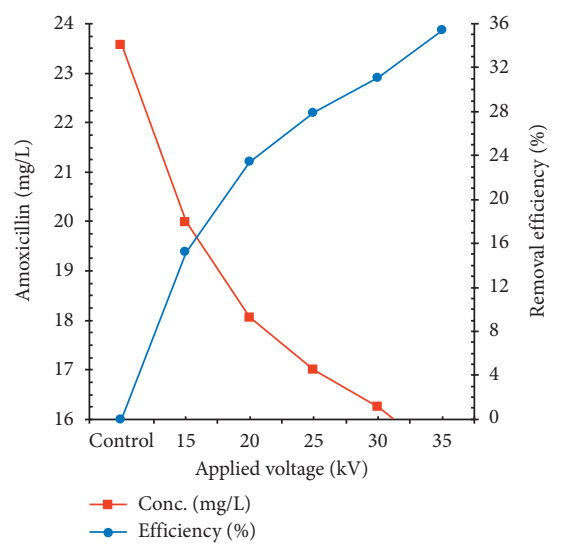

(d)



(b)

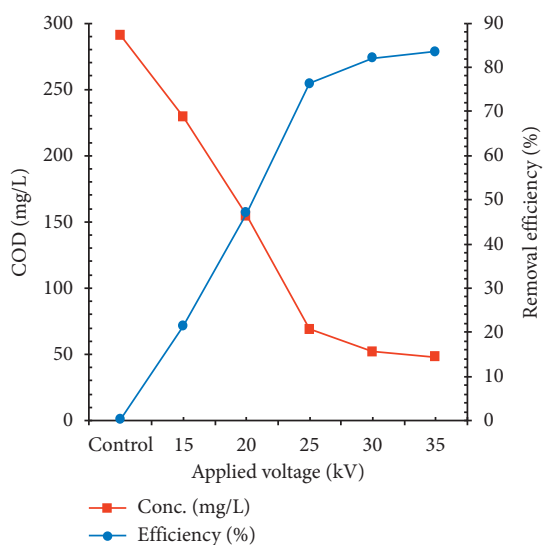

(e)

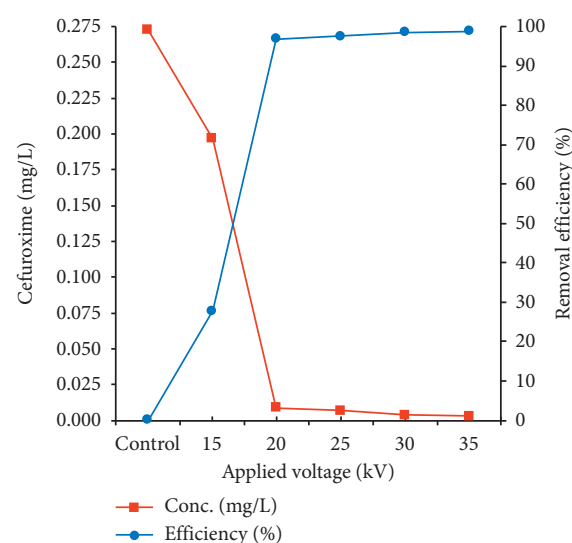

(c)

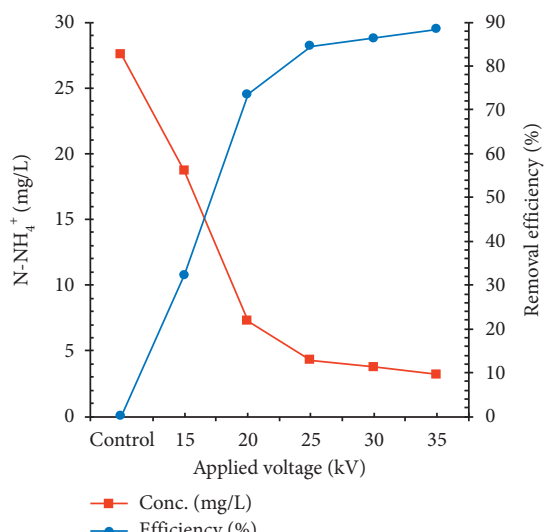

(f)

Figure 2: Effect of the applied voltage on the degradation efficiency of the four antibiotics, i.e., (a) ofloxacin, (b) ciprofloxacin, (c) cefuroxime, and (d) amoxicillin, respectively, as well as (e) COD and (f) ammonia removal.

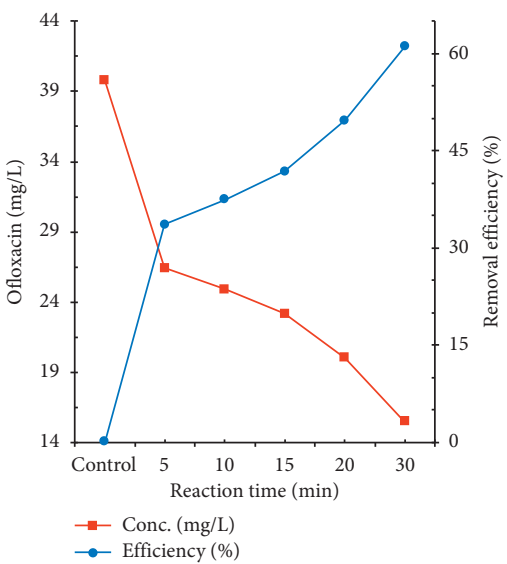

(a)

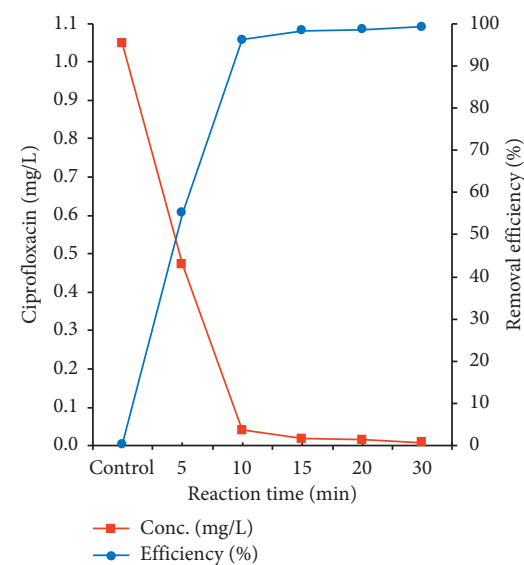

(b)

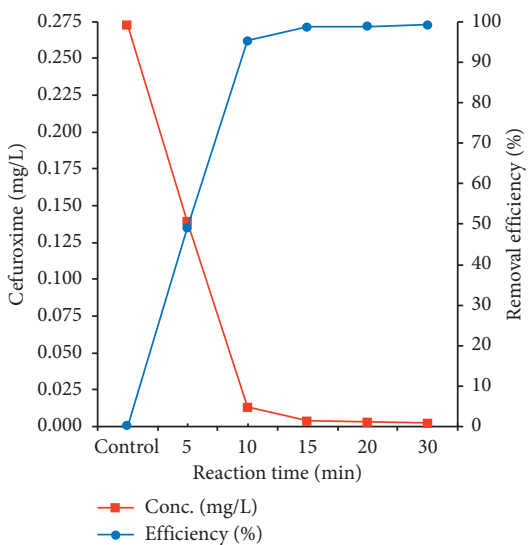

(c)

Figure 3: Continued. 


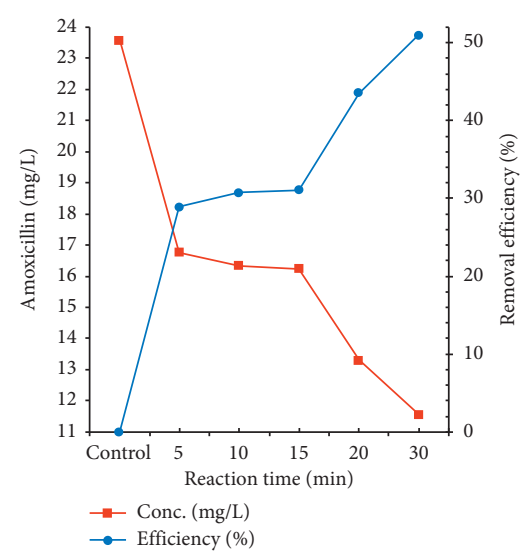

(d)

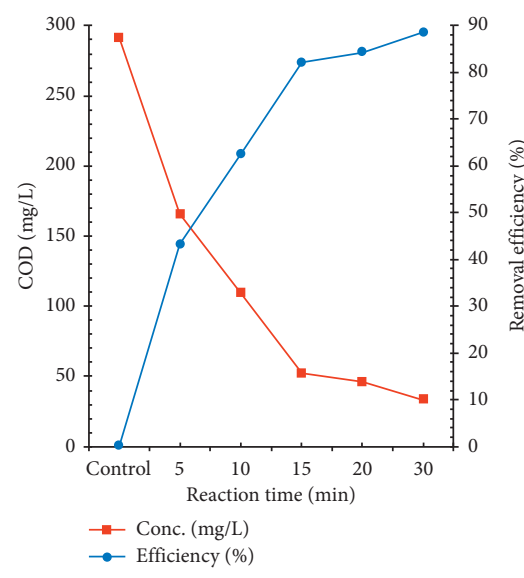

(e)

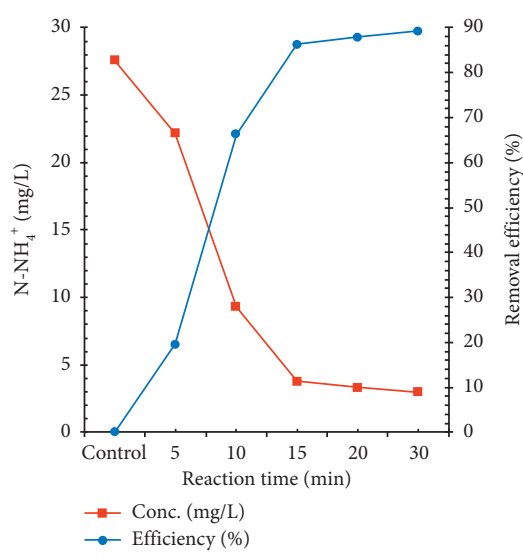

(f)

FIGURE 3: Effect of the reaction time on the degradation efficiency of four antibiotics, namely, (a) ofloxacin, (b) ciprofloxacin, (c) cefuroxime, and (d) amoxicillin, respectively, as well as (e) COD and (f) ammonia removal.

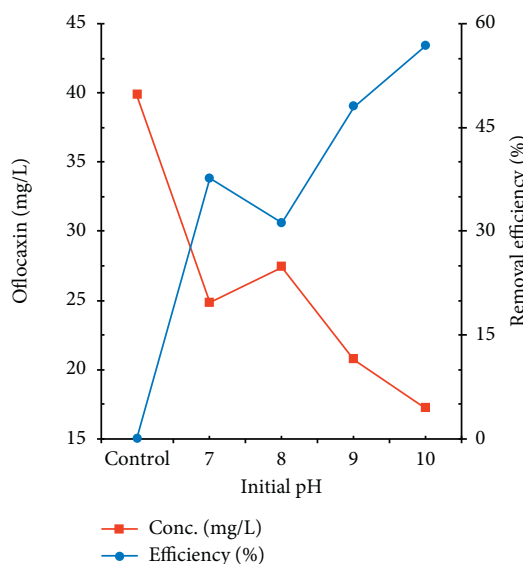

(a)

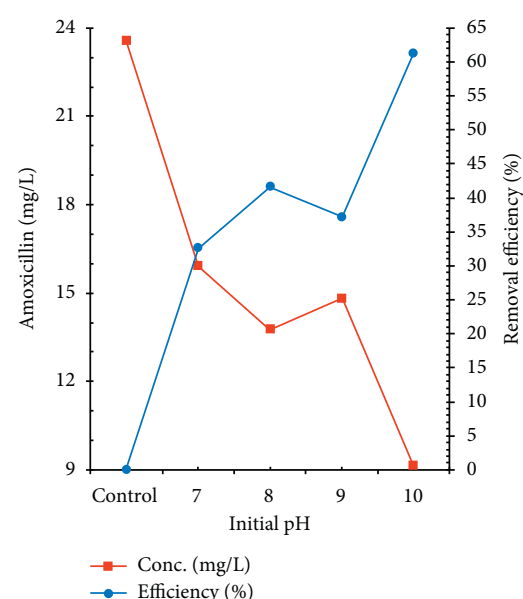

(d)

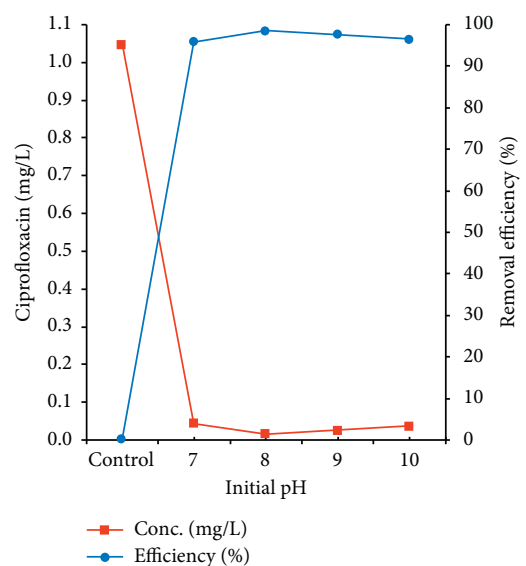

(b)

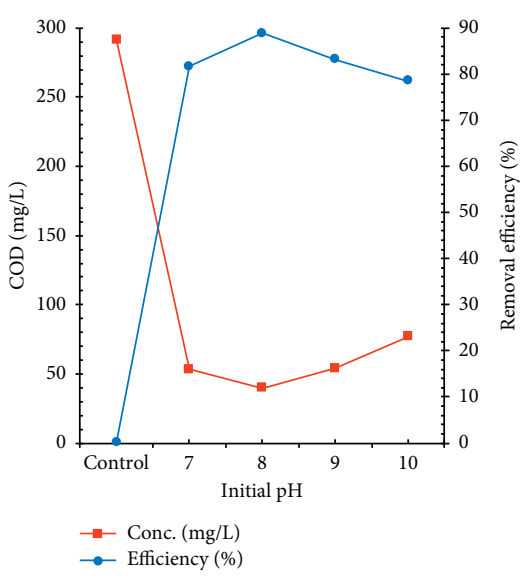

(e)

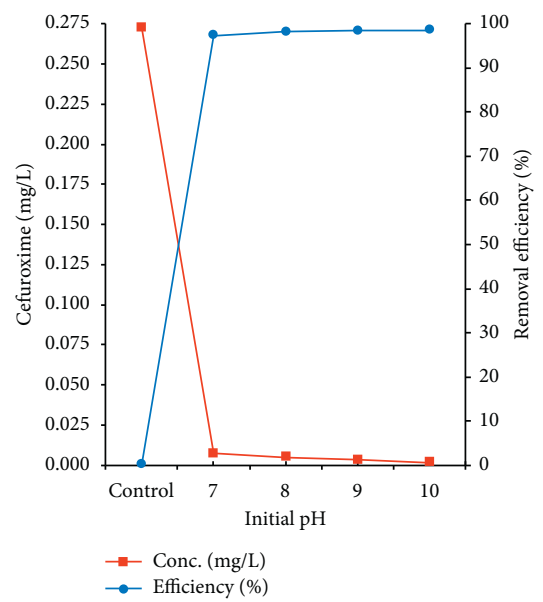

(c)

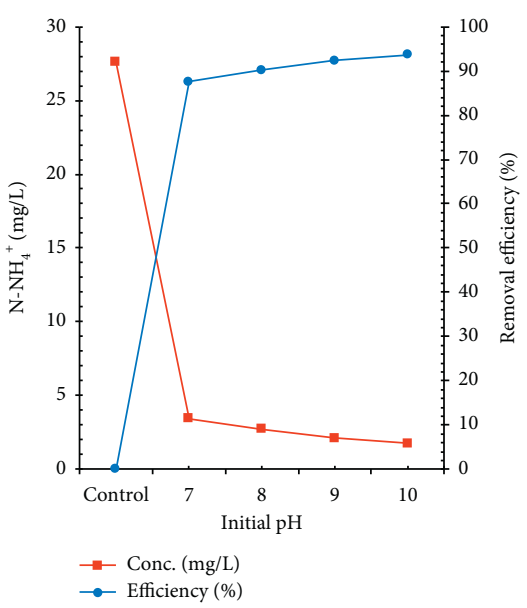

(f)

FIGURE 4: Effect of the pH on the degradation efficiency of four antibiotics, namely, (a) ofloxacin, (b) ciprofloxacin, (c) cefuroxime, and (d) amoxicillin, respectively, as well as (e) COD and (f) ammonia removal. Effect of the interelectrode distance of the plasma reactor. 
these antibiotics, COD, and ammonia increased. Three trends were observed during this treatment. In the case of ofloxacin and amoxicillin (Figures 4(a) and 4(d)), the variation in the removal efficiencies or breakpoint at $\mathrm{pH} 8$ (ofloxacin $31.18 \%$ ) and 9 (amoxicillin 41.63\%) was possibly related to the existing forms of the two antibiotics [35]. Notably, at $\mathrm{pH}$ values of 8 and 9 , the two antibiotics were dominated by negatively charged forms due to their higher $\mathrm{pH}$ values than the $\mathrm{pKa}$ values of the compounds. These forms could ineffectively react with $\cdot \mathrm{OH}$; hence, removal efficiencies decrease [35, 36]. All of the ciprofloxacin, cefuroxime, and COD (Figures 4(b)-4(e)) were completely degraded $(\sim 90 \%)$ at $\mathrm{pH} 8$; the further increase in the $\mathrm{pH}$ led to the slight reduction in the removal efficiency because, at a higher $\mathrm{pH}$ of 8 , the two antibiotics could be negatively charged forms, leading to decrease in the removal efficiency [37]. With the increase in the $\mathrm{pH}$, ammonia in the wastewater was eliminated extremely rapidly (>90\%) (Figure 4(f)). Two mechanisms were involved; first, the extent of oxidation of ammonia to nitrite or nitrate is increased by the produced oxidants under alkaline conditions as mentioned above; second, $\mathrm{N}-\mathrm{NH}_{4}{ }^{+}$can be transformed easily to $\mathrm{NH}_{3}$, which can evaporate under alkaline conditions during cold plasma treatment. These complex trends with the variation in $\mathrm{pH}$ during cold plasma treatment were in good agreement with those reported in previous studies [18, 27, 32]. A pH of 10 satisfied all parameters to attain the highest removal efficiency; therefore, this $\mathrm{pH}$ is selected for subsequent experiments.

A previous study has reported that the interelectrode distance in the plasma reactor can determine the amount of the formed $\cdot \mathrm{OH}$ [38], thereby affecting the degradation efficiency. The experiment was conducted by utilizing various electrode distances of 10-30 mm, pH 10, and an applied voltage of $30 \mathrm{kV}$ for a reaction time of $15 \mathrm{~min}$. Figure 5 shows the relationship between the pollutant concentration and removal efficiency to the electrode distance. The removal efficiency even slightly varied at an interelectrode distance of $25 \mathrm{~mm}$ for ofloxacin (Figure 5(a)) and at that of $30 \mathrm{~mm}$ for the other antibiotics (Figures 5(b)-5(d)); hence, the increase in the interelectrode distance leads to the significant decrease in the antibiotic removal efficiency. At an interelectrode distance of $10 \mathrm{~mm}$, the highest antibiotic removal efficiencies reached $72.13 \%, 99.60 \%, 99.20 \%$, and $75.80 \%$ for ofloxacin, ciprofloxacin, cefuroxime, and amoxicillin, respectively. The decrease in the removal efficiency with the increase in the electrode distances can be explained as follows: with the increase in the interelectrode distance, the possibility of electrical discharge is reduced, leading to the decrease in the electric-field energy generated to create the plasma and subsequently low production of oxidants during the plasma process. These results are consistent with those reported in some previous studies $[17,38,39]$; these studies indicated that a suitable two-electrode spacing from 8 to $20 \mathrm{~mm}$ not only improves the formation of oxidants but also accelerates the temperature during the plasma process, leading to the mitigation of a high concentration of pollutants. In the case of COD and ammonia, with the increase in the interelectrode distance, even the removal efficiency decreased, albeit with an insignificant decrease. The highest removal efficiencies of $84.23 \%$ and $98.60 \%$ for COD and ammonia were observed at an interelectrode distance of $10 \mathrm{~mm}$, respectively, while the lowest values of $73.17 \%$ and $76.40 \%$, respectively, were observed at an interelectrode distance of $30 \mathrm{~mm}$. These results demonstrated the effectiveness of the plasma process for the disinfection of HWW. Hence, an interelectrode distance of $10 \mathrm{~mm}$ may be a suitable alternative for subsequent experiments for oxidant formation during the plasma process.

3.3. Formation of Oxidizing Agents $\mathrm{O}_{3}, \mathrm{H}_{2} \mathrm{O}_{2}$, and $\cdot \mathrm{OH}$. As mentioned above, cold plasma generates several oxidizing species, such as radicals $(\cdot \mathrm{OH}, \cdot \mathrm{H})$ and molecules $\left(\mathrm{O}_{3}\right.$ and $\mathrm{H}_{2} \mathrm{O}_{2}$ ); among these species, the hydroxyl radical is considered to be a powerful nonselective oxidant [25]. The process formed free $\cdot \mathrm{OH}$ as $\mathrm{O}_{3}$ was dissolved in water-based eqs (3)-(10):

$$
\begin{gathered}
\mathrm{O}_{2}+e^{-} \longrightarrow 2 \mathrm{O}+e^{-} \\
\mathrm{O}_{2}+\mathrm{O} \cdot \longrightarrow \mathrm{O}_{3} \\
\mathrm{O}_{3}+\mathrm{OH}^{-} \longrightarrow \mathrm{O}_{3}^{--}+\cdot \mathrm{OH} \\
\mathrm{O}_{3}^{--} \longrightarrow \mathrm{O}^{--}+\mathrm{O}_{2} \\
\mathrm{O}^{--}+\mathrm{H}_{2} \mathrm{O} \cdot \mathrm{OH}+\mathrm{OH}^{-} \\
3 \mathrm{O}_{3}+\mathrm{H}_{2} \mathrm{O} \longrightarrow 2 \cdot \mathrm{OH}+4 \mathrm{O}_{2} \\
\mathrm{O}_{3}+\mathrm{HO}_{2 \cdot} \longrightarrow \cdot \mathrm{OH}^{-} \mathrm{O}_{2} \mathrm{O}_{2}^{-} \\
\mathrm{HO}_{2}+\mathrm{HO}_{2 \cdot} \longrightarrow \mathrm{H}_{2} \mathrm{O}_{2}+\mathrm{O}_{2} \\
\mathrm{H}_{2} \mathrm{O}_{2}+\mathrm{O}_{3} \longrightarrow \cdot \mathrm{OH}+\mathrm{O}_{2}+\cdot \mathrm{HO}_{2}
\end{gathered}
$$

Hydroxyl radicals were formed by a collision between energetic electrons and $\mathrm{H}_{2} \mathrm{O}$ vapour molecules.

$$
e^{-}+\mathrm{H}_{2} \mathrm{O} \longrightarrow \cdot \mathrm{OH}+\mathrm{H} \cdot+e^{-}
$$

In addition, $\cdot \mathrm{OH}$ radicals were formed by the reaction between oxygen and water vapour molecules.

$$
\mathrm{O}_{2}+2 \mathrm{H}_{2} \mathrm{O} \longrightarrow 2 \cdot \mathrm{OH}+2 \cdot \mathrm{OH}
$$

Recombination of free radicals also possibly decreased the mitigation capacity according to the following equations (14) and (15) [40].

$$
\begin{gathered}
\cdot \mathrm{OH}+\cdot \mathrm{OH} \longrightarrow \mathrm{H}_{2} \mathrm{O}_{2} \\
\mathrm{HO}_{2}+\cdot \mathrm{OH} \longrightarrow \mathrm{O}_{2}+\mathrm{H}_{2} \mathrm{O}
\end{gathered}
$$

Experimentswere conducted to investigate the effects of $\mathrm{pH}$ and reaction time on the formation of $\mathrm{O}_{3}, \mathrm{H}_{2} \mathrm{O}_{2}$ and. $\mathrm{OH}$.

3.4. Effect of $\mathrm{pH}$ on the Formation of $\mathrm{O}_{3}, \mathrm{H}_{2} \mathrm{O}_{2}$, and $\cdot \mathrm{OH}$. The content of oxidizing agents generated by variation in the $\mathrm{pH}$ value $(4,6,8,10$, and 12) while simultaneously 


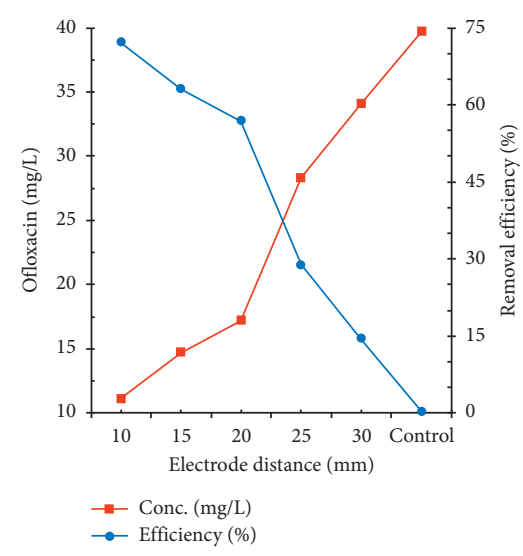

(a)

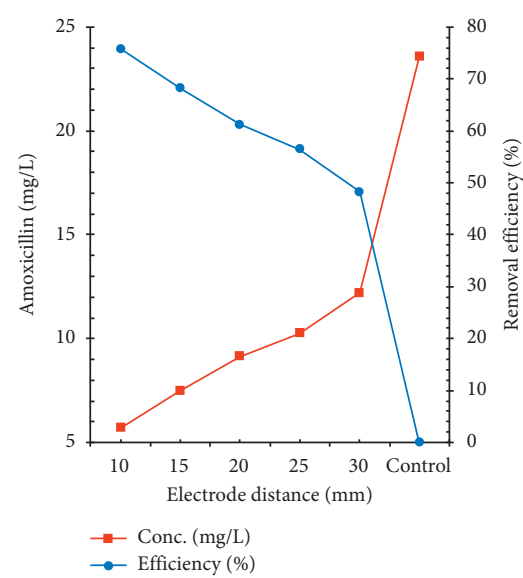

(d)

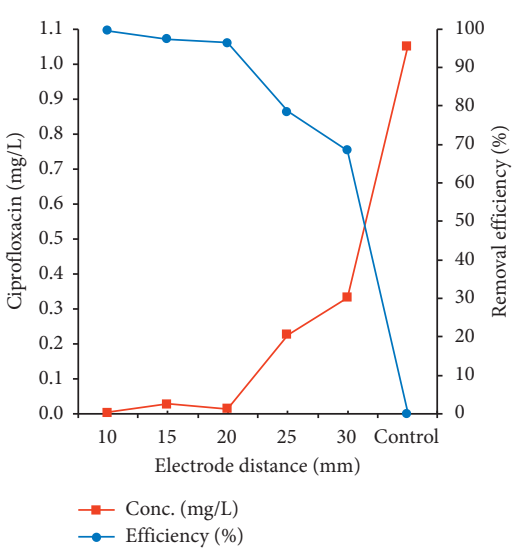

(b)

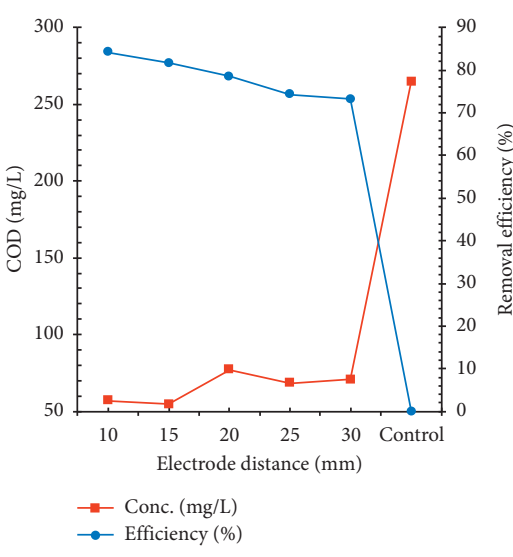

(e)

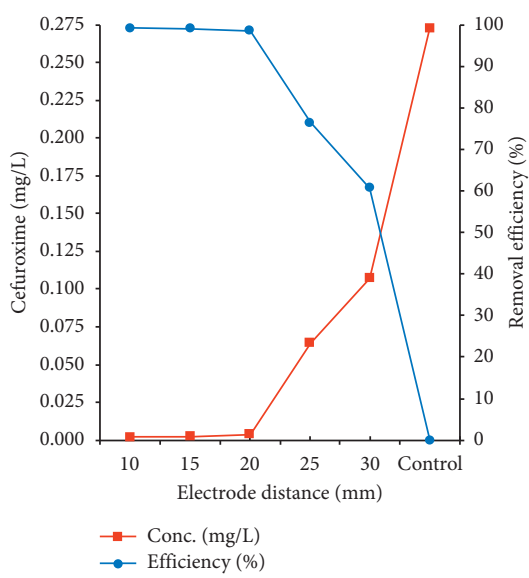

(c)

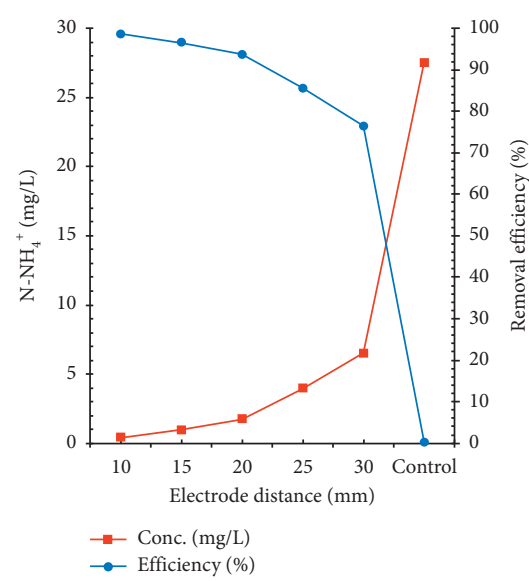

(f)

FIGURE 5: Effect of the interelectrode distance in the plasma reactor on the degradation efficiency of four antibiotics, namely, (a) ofloxacin, (b) ciprofloxacin, (c) cefuroxime and (d) amoxicillin, respectively, as well as (e) COD and (f) ammonia removal.

maintaining the other parameters constant, i. e., an applied voltage of $30 \mathrm{kV}$, a reaction time of $15 \mathrm{~min}$, and an interelectrode distance of $10 \mathrm{~mm}$. As can be observed in Figures 6(a) and 6(b), with the increase in the $\mathrm{pH}$ from acidic to alkaline conditions $(3.4 \mathrm{mM}$ and $0.05 \mathrm{mM})$, the highest concentrations of ozone and $\mathrm{H}_{2} \mathrm{O}_{2}$ were observed, with the highest detected under acidic conditions $(4.8 \mathrm{mM}$ and $0.18 \mathrm{mM}$ ), and the decomposition rate of these compounds sharply increased. These results are in good agreement with those reported by Kuo et al. [41], where the author reported that in the plasma process, with the increase in $\mathrm{pH}$, the reaction between ozone and $\mathrm{H}_{2} \mathrm{O}_{2}$ can be accelerated to produce $\cdot \mathrm{OH}$ (a stronger oxidant), as shown in equation (11), leading to the decrease in the concentrations of ozone and $\mathrm{H}_{2} \mathrm{O}_{2}$ in the aqueous phase. These explanations can be confirmed by the predominant formation of $\cdot \mathrm{OH}$ under alkaline conditions (Figure 6(c)): with the increase in the $\mathrm{pH}$ from 4 to 6 , the $\cdot \mathrm{OH}$ concentration only slightly increased from $0.052 \mathrm{mM}$ to $0.06 \mathrm{mM}$. Nevertheless, with the increase in the $\mathrm{pH}$ to $10(0.215 \mathrm{mM})$, the $\cdot \mathrm{OH}$ concentration dramatically increased. The sudden drop in the $\cdot \mathrm{OH}$ concentration to $0.17 \mathrm{mM}$ at pH 12 may be explained by the fact that most of the $\cdot \mathrm{OH}$ reacted with pollutants in the wastewater.
These results also again demonstrated the enhanced formation and removal efficiency of $\cdot \mathrm{OH}$ under alkaline conditions by the Nernst equation [33].

3.5. Effects of the Reaction Time on the Formation of $\mathrm{O}_{3}, \mathrm{H}_{2} \mathrm{O}_{2}$, and $\cdot \mathrm{OH}$. Reaction time was directly related to the formation of active radicals; hence, its effect on the production of radicals is examined. The reaction time was adjusted from 2 min to 10 min while simultaneously maintaining an applied voltage of $30 \mathrm{kV}$, a $\mathrm{pH}$ of 10 , and an interelectrode distance of $10 \mathrm{~mm}$. At a long reaction time, the $\mathrm{O}_{3}$ concentration increased (Figure 7(a)). At a reaction time of $2 \mathrm{~min}$, the ozone concentration was $1.2 \mathrm{mM}$, which slightly increased at a reaction time of $3 \mathrm{~min}$. The generated ozone concentration was $3.9 \mathrm{mM}$ (greater than 3.2 times), while the reaction time increased only by $1 \mathrm{~min}$. At a reaction time of $10 \mathrm{~min}$, the ozone concentration was $8.0 \mathrm{mM}$ (6.7 times greater than that observed in $2 \mathrm{~min}$ ). Similar trends observed for the formation of $\mathrm{H}_{2} \mathrm{O}_{2}$ (Figure $7(\mathrm{~b})$ ): the $\mathrm{H}_{2} \mathrm{O}_{2}$ concentration notably increased from $0.076 \mathrm{mM}$ at $2 \mathrm{~min}$ to $0.23 \mathrm{mM}$ at $5 \mathrm{~min}$. The $\mathrm{H}_{2} \mathrm{O}_{2}$ concentration was $0.076 \mathrm{mM}$ at a reaction time of $2 \mathrm{~min}$. With the further increase in 


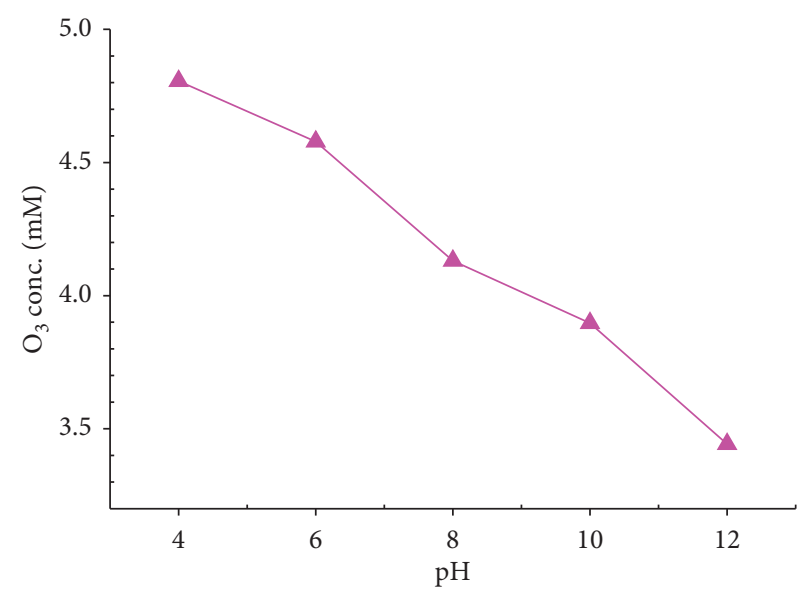

(a)



(b)



(c)

Figure 6: Effect of $\mathrm{pH}$ on the formation of (a) $\mathrm{O}_{3},\left(\right.$ b) $\mathrm{H}_{2} \mathrm{O}_{2}$, and (c) $\cdot \mathrm{OH}$.

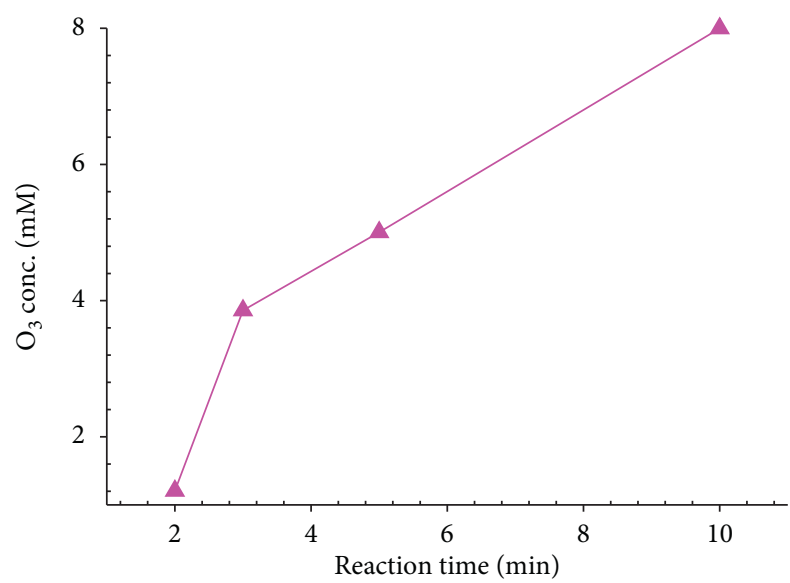

(a)

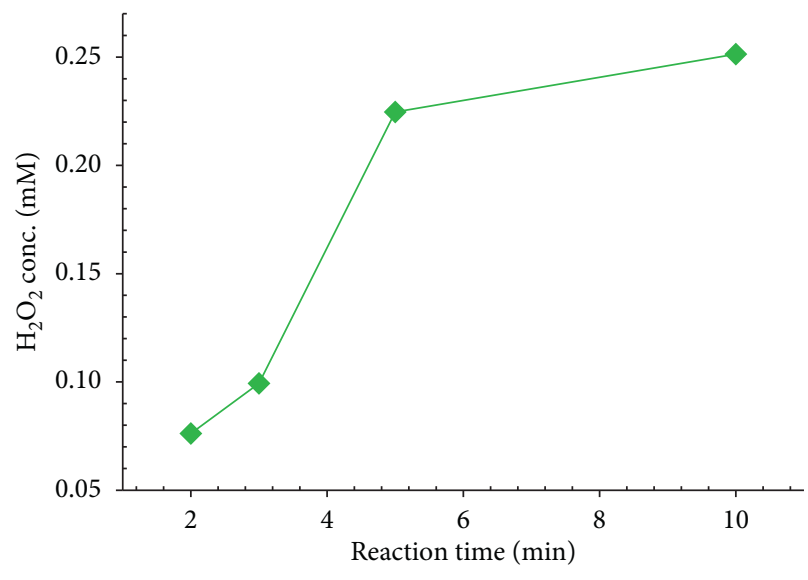

(b)

Figure 7: Continued. 


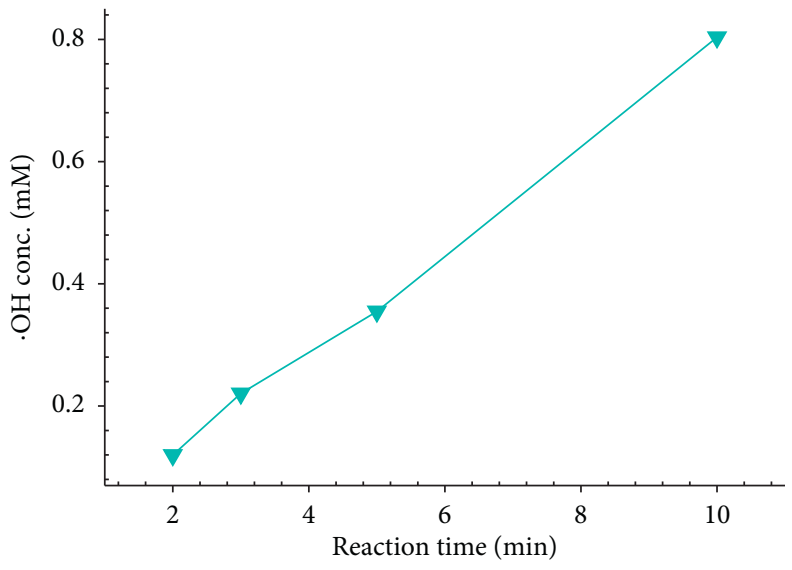

(c)

Figure 7: Effect of the reaction time on the formation of (a) $\mathrm{O}_{3},(b) \mathrm{H}_{2} \mathrm{O}_{2}$, and (c) $\cdot \mathrm{OH}$.

TABle 1: Reaction kinetics models for the decomposition of four antibiotics.

\begin{tabular}{|c|c|c|c|c|c|c|}
\hline Antibiotics & Initial conc. $(\mathrm{mg} / \mathrm{L})$ & Reaction order & Regression equation & $R^{2}$ & Rate constant & $t_{1 / 2}(\mathrm{~min})$ \\
\hline \multirow{3}{*}{ Ofloxacin } & \multirow{3}{*}{41.23} & 1 & $y=0.0333 x+0.0993$ & 0.9214 & $0.0333(1 / \mathrm{min})$ & 20.82 \\
\hline & & 2 & $y=0.0014 x+0.0258$ & 0.9737 & 0.0014 (L/mg.min) & 17.32 \\
\hline & & 3 & $y=0.0001 x+0.0005$ & 0.9896 & $\mathbf{5} \times \mathbf{1 0}^{-\mathbf{5}}\left(\mathrm{L}^{2} / \mathrm{mg}^{2} \cdot \mathrm{min}\right)$ & 1.76 \\
\hline \multirow{3}{*}{ Ciprofloxacin } & \multirow{3}{*}{1.052} & 1 & $y=0.2332 x-0.082$ & 0.9790 & $0.2332(1 / \mathrm{min})$ & 2.97 \\
\hline & & 2 & $y=0.6232 x+0.2062$ & 0.8349 & 0.6232 (L/mg.min) & 1.53 \\
\hline & & 3 & $y=4.2432 x-6.4031$ & 0.6643 & $2.122\left(\mathrm{~L}^{2} / \mathrm{mg}^{2} \cdot \mathrm{min}\right)$ & 0.64 \\
\hline \multirow{3}{*}{ Cefuroxime } & \multirow{3}{*}{0.273} & 1 & $y=0.2421 x-0.0918$ & 0.9626 & $0.2421(1 / \mathrm{min})$ & 2.86 \\
\hline & & 2 & $y=2.6828 x+0.234$ & 0.7739 & 2.683 (L/mg.min) & 1.37 \\
\hline & & 3 & $y=79.501 x-131.03$ & 0.5925 & $39.75\left(\mathrm{~L}^{2} / \mathrm{mg}^{2} \cdot \mathrm{min}\right)$ & 0.51 \\
\hline \multirow{3}{*}{ Amoxicillin } & \multirow{3}{*}{23.58} & 1 & $y=0.0319 x+0.195$ & 0.9107 & $0.0319(1 / \mathrm{min})$ & 21.73 \\
\hline & & 2 & $y=0.0026 x+0.0498$ & 0.9711 & 0.0026 (L/mg.min) & 16.31 \\
\hline & & 3 & $y=0.0004 x+0.002$ & 0.9826 & $\mathbf{2} \times \mathbf{1 0}^{-\mathbf{4}}\left(\mathrm{L}^{2} / \mathrm{mg}^{2} \cdot \mathrm{min}\right)$ & 13.49 \\
\hline
\end{tabular}

reaction time up to $10 \mathrm{~min}$, the $\mathrm{H}_{2} \mathrm{O}_{2}$ concentration only reached $0.25 \mathrm{mM}$, indicating that when the reaction time is doubled, the concentration increase of $\mathrm{H}_{2} \mathrm{O}_{2}$ is only about $0.02 \mathrm{mM}$. Compared to $\mathrm{H}_{2} \mathrm{O}_{2}$ or $\mathrm{O}_{3}$, the $\cdot \mathrm{OH}$ concentration increased almost linearly with the reaction time and reached the highest concentration of $0.8 \mathrm{mM}$ at $10 \mathrm{~min}$ (Figure $7(\mathrm{c})$ ). These results are apparently in agreement with those reported previously on the use of plasma to eliminate pollutants from aqueous solutions [17, 21-23].

3.6. Reaction Kinetic Models for the Decomposition of Antibiotics. To obtain further insights into the reaction kinetics for the decomposition of the antibiotics by cold plasma treatment, the change in the concentration of substances over the reaction time under optimum conditions was carefully investigated. The investigated reaction kinetics models included first-order kinetics, second-order kinetics, and third-order kinetics as reported in our previous studies $[15,16]$. Table 1 and Figure S2 show the results obtained, i. e., rate constants, reaction orders, and squared correlation coefficients. The first-order reaction kinetics model revealed the highest squared correlation coefficient for the decomposition of ciprofloxacin and cefuroxime (0.9790 and 0.9626, respectively). Meanwhile, these squared correlation coefficients were the highest for the third-order kinetics reaction of the decomposition of ofloxacin and amoxicil$\operatorname{lin}(0.9896$ and 0.9826 , respectively).

Table 2 below summarizes the removal efficiencies for antibiotics using cold plasma reported in recent studies. In addition to the Corona plasma systems similar to those used herein, other plasma systems such as DBD were utilized. Specifically, only this study discussed real wastewater containing a high concentration, as well as mixed contaminants, of antibiotics compared to a single antibiotic in an aqueous solution or synthetic wastewater in the references. In a shorter time, this study reaches a suitable result as compared with other reference studies. The removal efficiencies of all antibiotics were extremely high (>99\% for cefuroxime and ciprofloxacin and $>72 \%$ for amoxicillin and ofloxacin). These values are greater than the treatment efficiencies of tetracycline $(61.9 \%)$ and $\beta$-oestradiol (70\%) reported in studies by $\mathrm{He}$ et al. [23] and Panorel et al. [24], respectively. The lower removal results for mixed compounds compared to individual compounds using AOPs can be found in some previous studies $[42,43]$. 
TABLE 2: Some recent findings of cold plasma treatment for the elimination of antibiotic compounds in water or wastewater.

\begin{tabular}{|c|c|c|c|c|}
\hline Antibiotics & Matrix & Plasma conditions & Efficiency (\%) & References \\
\hline Ofloxacin ciprofloxacin & $\begin{array}{l}\text { Synthetic meat effluent }(10 \mathrm{mg} / \\
\mathrm{L} \text { antibiotics })\end{array}$ & $\begin{array}{l}\text { DBD reactor }(25 \mathrm{~mL}) \text {, applied } \\
\text { voltage of } 80 \mathrm{kV} \text {, degradation } \\
\text { kinetics: first-order, during a } \\
\text { reaction time of } 25 \mathrm{~min}\end{array}$ & $\begin{array}{c}\text { Ofloxacin } 92 \% \\
\text { Ciprofloxacin } 89 \%\end{array}$ & [21] \\
\hline $\begin{array}{l}\text { Carbamazepine clofibric acid } \\
\text { iopromide }\end{array}$ & $\begin{array}{c}\text { Aqueous solution and synthetic } \\
\text { landfill leachate carbamazepine } \\
(23.6 \mathrm{mg} / \mathrm{L}), \text { clofibric acid } \\
(21.5 \mathrm{mg} / \mathrm{L}) \text {, iopromide } \\
(79.1 \mathrm{mg} / \mathrm{L})\end{array}$ & $\begin{array}{c}\text { DBD-rotating drum reactor } \\
(1000 \mathrm{~mL}) \text {, discharge power of } \\
500 \mathrm{~W} \text { during, reaction time of } \\
60 \mathrm{~min}\end{array}$ & $\begin{array}{c}\text { Carbamazepine } \\
94 \% \\
\text { Clofibric acid } 100 \% \\
\text { Iopromide } 98 \%\end{array}$ & {$[22]$} \\
\hline Tetracycline & Aqueous solution $(50 \mathrm{mg} / \mathrm{L})$ & $\begin{array}{c}\text { Corona with gas bubbling } \\
(250 \mathrm{~mL}) \text {, discharge power of } \\
36 \mathrm{~W} \text { during a reaction time of } \\
24 \mathrm{~min}\end{array}$ & $61.9 \%$ & {$[23]$} \\
\hline Paracetamol $\beta$-oestradiol & $\begin{array}{c}\text { Aqueous solution of } \\
\text { paracetamol }(100 \mathrm{mg} / \mathrm{L}) \\
\beta \text {-oestradiol }(3 \mathrm{mg} / \mathrm{L})\end{array}$ & $\begin{array}{c}\text { Corona with liquid shower } \\
(40 \mathrm{~L}) \text {, discharge power of } 250 \mathrm{~W} \\
\text { during a reaction time of } 30 \mathrm{~min} \\
\end{array}$ & $\begin{array}{l}\text { Paracetamol } 80 \% \\
\beta \text {-Oestradiol } 70 \%\end{array}$ & {$[24]$} \\
\hline $\begin{array}{l}\text { Lincomycin, ciprofloxacin, } \\
\text { enrofloxacin, chlortetracycline, } \\
\text { oxytetracycline, sulfathiazole, } \\
\text { sulfamethoxazole, sulfamethazine } \\
\text { trimethoprim }\end{array}$ & $\begin{array}{l}\text { Aqueous solution }(5 \mathrm{mg} / \mathrm{L} \\
\text { antibiotics) }\end{array}$ & $\begin{array}{c}\text { Cylindrical DBD reactor } \\
(1000 \mathrm{~mL}) \text {, supplied } \mathrm{O}_{2}, \\
\text { discharge power of } 6.8 \mathrm{~W} \\
\text { corresponding energy } \\
\text { requirements: } 0.39-2.06 \mathrm{~kJ} / \mathrm{mg} \\
\text { antibiotic during a reaction time } \\
\text { of } 30 \mathrm{~min}\end{array}$ & Over $90 \%$ & {$[27]$} \\
\hline $\begin{array}{l}\text { Amoxicillin cefuroxime ofloxacin } \\
\text { ciprofloxacin }\end{array}$ & $\begin{array}{c}\text { Real HWW amoxicillin } \\
(23.58 \mathrm{mg} / \mathrm{L}), \text { cefuroxime } \\
(0.273 \mathrm{mg} / \mathrm{L}) \text {, ofloxacin } \\
\text { (41.23 mg/L), ciprofloxacin } \\
(1.052 \mathrm{mg} / \mathrm{L})\end{array}$ & $\begin{array}{l}\text { Corona with a liquid discharge } \\
\text { system }(600 \mathrm{~mL}) \text {, applied voltage } \\
\text { of } 30 \mathrm{kV} \text {, initial } \mathrm{pH} \text { of } 10 \text {, and an } \\
\text { interelectrode distance of } 10 \mathrm{~mm} \\
\text { during a reaction time of } 15 \mathrm{~min}\end{array}$ & $\begin{array}{c}\text { Amoxicillin } 75.80 \% \\
\text { Cefuroxime } 99.20 \% \\
\text { Ofloxacin } 72.13 \%, \\
\text { ciprofloxacin } \\
99.60 \% \\
\end{array}$ & This study \\
\hline
\end{tabular}

\section{Conclusions}

In this study, the cold plasma technique was demonstrated to be a simple, efficient method for eliminating antibiotic contaminants from real hospital wastewater in Ho Chi Minh City, Vietnam. The degradation efficiency of these antibiotic compounds was considerably dependent on the initial $\mathrm{pH}$ and reaction time as it possibly affected the formation of oxidants (such as $\mathrm{O}_{3}, \mathrm{H}_{2} \mathrm{O}_{2}$, and $\cdot \mathrm{OH}$ ) during the plasma process. The obtained results also indicated that the applied voltage and electrode distance affect the treatment process. Under the optimum conditions (initial $\mathrm{pH}$ of 10 , electrode distance of $10 \mathrm{~mm}$, reaction time of $15 \mathrm{~min}$, and applied voltage of $30 \mathrm{kV}$ ), the removal efficiencies of all antibiotics were high $(>72 \%$ for ciprofloxacin and cefuroxime and $>99 \%$ for amoxicillin and ofloxacin), in addition to the complete removal of COD and ammonia. The significant formation of $\cdot \mathrm{OH}$ and rapid decomposition of $\mathrm{O}_{3}$ and $\mathrm{H}_{2} \mathrm{O}_{2}$ under alkaline conditions might prove to play a key role in the production of $\mathrm{OH}$ during this plasma treatment for such contaminants. In this study, contamination by the four antibiotics also was detected in the effluent of seven hospitals in Ho Chi Minh City, directly leading to the environment. Such environmental pollution could be alarming due to the antibiotic pollutants from the hospital wastewater in Vietnam.

\section{Data Availability}

The data used are included in the manuscript.

\section{Conflicts of Interest}

The authors declare that they have no conflicts of interest.

\section{Acknowledgments}

The authors thank the Ho Chi Minh Department of Science and Technology, Vietnam, for the support through the project code: 77/2019/HĐ-QPTKHCN.

\section{Supplementary Materials}

Supplemental Table. Table S1: Evaluated factors and their established ranges for the plasma tests. Table S2: Characterization of wastewater from the seven hospitals. Supplemental Figure. Figure S1: The study area and regional map (a). Ho Chi Minh City area (b), and Hospital sampling site in Ho Chi Minh City (c). Figure S2: Third-order reaction kinetics models of (a) ofloxacin and (b) amoxicillin, and firstorder reaction kinetics models of (c) ciprofloxacin and (d) cefuroxime. (Supplementary Materials)

\section{References}

[1] J. B. Carbajo, A. L. Petre, R. Rosal et al., "Continuous ozonation treatment of ofloxacin: transformation products, water matrix effect and aquatic toxicity," Journal of Hazardous Materials, vol. 292, pp. 34-43, 2015.

[2] N. Hassoun-Kheir, Y. Stabholz, J.-U. Kreft et al., "Comparison of antibiotic-resistant bacteria and antibiotic resistance genes 
abundance in hospital and community wastewater: a systematic review," Science of The Total Environment, vol. 743, pp. 1-11, 2020.

[3] S. Bergeron, R. Boopathy, R. Nathaniel, A. Corbin, and G. LaFleur, "Presence of antibiotic resistant bacteria and antibiotic resistance genes in raw source water and treated drinking water," International Biodeterioration \& Biodegradation, vol. 102, pp. 370-374, 2015.

[4] H. Q. Anh, T. P. Q. Le, N. Da Le et al., "Antibiotics in surface water of East and Southeast Asian countries: a focused review on contamination status, pollution sources, potential risks, and future perspectives," Science of The Total Environment, vol. 764, p. 142865, 2021.

[5] N. A. Khan, S. Ahmed, I. H. Farooqi et al., "Occurrence, sources and conventional treatment techniques for various antibiotics present in hospital wastewaters: a critical review," TrAC Trends in Analytical Chemistry, vol. 129, Article ID 115921, 2020.

[6] S. Yousefzadeh, E. Ahmadi, M. Gholami et al., "A comparative study of anaerobic fixed film baffled reactor and up-flow anaerobic fixed film fixed bed reactor for biological removal of diethyl phthalate from wastewater: a performance, kinetic, biogas, and metabolic pathway study," Biotechnology for Biofuels, vol. 10, p. 139, 2017.

[7] E. Ahmadi, B. Kakavandi, A. Azari et al., "The performance of mesoporous magnetite zeolite nanocomposite in removing dimethyl phthalate from aquatic environments," Desalination and Water Treatment, vol. 57, pp. 27768-27782, 2016.

[8] D. J. Naghan, A. Azari, N. Mirzaei et al., "Parameters effecting on photocatalytic degradation of the phenol from aqueous solutions in the presence of $\mathrm{ZnO}$ nanocatalyst under irradiation of UV-C light," Bulgarian Chemical Communications, vol. 47, pp. 14-18, 2015.

[9] P. Chinnaiyan, S. G. Thampi, M. Kumar, and M. Balachandran, "Photocatalytic degradation of metformin and amoxicillin in synthetic hospital wastewater: effect of classical parameters," International Journal of Environmental Science and Technology, vol. 16, no. 10, pp. 5463-5474, 2019.

[10] K. M. S. Hansen, A. Spiliotopoulou, R. K. Chhetri, M. Escolà Casas, K. Bester, and H. R. Andersen, "Ozonation for source treatment of pharmaceuticals in hospital wastewater - ozone lifetime and required ozone dose," Chemical Engineering Journal, vol. 290, pp. 507-514, 2016.

[11] Y. Qian, X. Liu, K. Li et al., "Enhanced degradation of cephalosporin antibiotics by matrix components during thermally activated persulfate oxidation process," Chemical Engineering Journal, vol. 384, Article ID 123332, 2020.

[12] M. Yegane Badi, S. Fallah Jokandan, A. Esrafili et al., "Optimization of advanced oxidation process based on persulfate (Uv/ $\mathrm{Na}_{2} \mathrm{~S}_{2} \mathrm{O}_{8} / \mathrm{Fe}_{2}+$ ) for phthalic acid removal from aqueous solutions with response surface methodology," Journal of Babol University of Medical Sciences, vol. 20, pp. 13-21, 2018.

[13] S. Ahmadzadeh and M. Dolatabadi, "Removal of acetaminophen from hospital wastewater using electro-Fenton process," Environmental Earth Sciences, vol. 77, pp. 1-11, 2018.

[14] R. Changotra, J. P. Guin, S. A. Khader, L. Varshney, and A. Dhir, "Electron beam induced degradation of ofloxacin in aqueous solution: kinetics, removal mechanism and cytotoxicity assessment," Chemical Engineering Journal, vol. 356, pp. 973-984, 2019.

[15] N. N. Duy, T. N. Hieu, T. P. Luu et al., "Removal of leucomalachite green in an aqueous solution by the electron beam process," Journal of Water Process Engineering, vol. 40, Article ID 101781, 2020.
[16] D. N. Nguyen, H. T. Nguyen, T.-L. Pham et al., "Degradation of tricyclazole from aqueous solution and real wastewater by electron-beam irradiation," Environmental Technology \& Innovation, vol. 21, Article ID 101315, 2021.

[17] H. Zeghioud, P. Nguyen-Tri, L. Khezami, A. Amrane, and A. A. Assadi, "Review on discharge Plasma for water treatment: mechanism, reactor geometries, active species and combined processes," Journal of Water Process Engineering, vol. 38, Article ID 101664, 2020.

[18] C. Sarangapani, N. N. Misra, V. Milosavljevic, P. Bourke, F. O'Regan, and P. J. Cullen, "Pesticide degradation in water using atmospheric air cold plasma," Journal of Water Process Engineering, vol. 9, pp. 225-232, 2016.

[19] H.-J. Kim, C.-H. Won, and H.-W. Kim, "Pathogen deactivation of glow discharge cold plasma while treating organic and inorganic pollutants of slaughterhouse wastewater," Water, Air, \& Soil Pollution, vol. 229, pp. 1-10, 2018.

[20] L. H. Tecer, A. Gündüz, R. Atav, S. Soysal, and F. Yıldız, "Investigation of the treatment of textile wastewater with cold atmospheric plasma reactor (profoks) and reuse of recycled water in reactive dyeing process of cotton," Journal of Natural Fibers, vol. 40, pp. 1-8, 2020.

[21] C. Sarangapani, D. Ziuzina, P. Behan et al., "Degradation kinetics of cold plasma-treated antibiotics and their antimicrobial activity," Scientific Reports, vol. 9, pp. 1-15, 2019.

[22] H. Krause, B. Schweiger, E. Prinz, J. Kim, and U. Steinfeld, "Degradation of persistent pharmaceuticals in aqueous solutions by a positive dielectric barrier discharge treatment," Journal of Electrostatics, vol. 69, no. 4, pp. 333-338, 2011.

[23] D. He, Y. Sun, L. Xin, and J. Feng, "Aqueous tetracycline degradation by non-thermal plasma combined with nanoTiO2," Chemical Engineering Journal, vol. 258, pp. 18-25, 2014.

[24] I. Panorel, S. Preis, I. Kornev, H. Hatakka, and M. LouhiKultanen, "Oxidation of aqueous pharmaceuticals by pulsed corona discharge," Environmental Technology, vol. 34, no. 7, pp. 923-930, 2013.

[25] P. Lukes and B. R. Locke, "Plasmachemical oxidation processes in a hybrid gas-liquid electrical discharge reactor," Journal of Physics D: Applied Physics, vol. 38, no. 22, pp. 4074-4081, 2005.

[26] J. Lou, N. Lu, J. Li, T. Wang, and Y. Wu, "Remediation of chloramphenicol-contaminated soil by atmospheric pressure dielectric barrier discharge," Chemical Engineering Journal, vol. 180, pp. 99-105, 2012.

[27] K.-S. Kim, C.-S. Yang, and Y. S. Mok, "Degradation of veterinary antibiotics by dielectric barrier discharge plasma," Chemical Engineering Journal, vol. 219, pp. 19-27, 2013.

[28] R. B. Baird, Standard Methods for the Examination of Water and Wastewater, 23rd, Water Environment Federation, American Public Health Association, Washington, DC, USA, 2017.

[29] ASTM E222-17, Standard Test Methods for Hydroxyl Groups Using Acetic Anhydride Acetylation, ASTM International, West Conshohocken, PA, USA, 2017.

[30] ASTM D6363-98(2013), Standard Test Method for Determination of Hydrogen Peroxide and Combined Organic Peroxides in Atmospheric Water Samples by Peroxidase Enzyme Fluorescence Method, ASTM International, West Conshohocken, PA, 2013.

[31] M. Magureanu, N. B. Mandache, and V. I. Parvulescu, "Degradation of pharmaceutical compounds in water by nonthermal plasma treatment," Water Research, vol. 81, pp. 124-136, 2015. 
[32] X. Liao, D. Liu, S. Chen, X. Ye, and T. Ding, "Degradation of antibiotic resistance contaminants in wastewater by atmospheric cold plasma: kinetics and mechanisms," Environmental Technology, vol. 42, no. 1, pp. 58-71, 2021.

[33] B. Nikravesh, A. Shomalnasab, A. Nayyer, N. Aghababaei, R. Zarebi, and F. Ghanbari, "UV/Chlorine process for dye degradation in aqueous solution: mechanism, affecting factors and toxicity evaluation for textile wastewater," Journal of Environmental Chemical Engineering, vol. 8, no. 5, Article ID 104244, 2020

[34] R. Xie, X. Meng, P. Sun et al., "Electrochemical oxidation of ofloxacin using a $\mathrm{TiO}_{2}$-based $\mathrm{SnO}_{2}$-Sb/polytetrafluoroethylene resin- $\mathrm{PbO}_{2}$ electrode: reaction kinetics and mass transfer impact," Applied Catalysis B: Environmental, vol. 203, pp. 515-525, 2017.

[35] T. Liu, Q. Xue, J. Jia et al., "New insights into the effect of $\mathrm{pH}$ on the mechanism of ofloxacin electrochemical detection in aqueous solution," Physical Chemistry Chemical Physics, vol. 21, no. 29, pp. 16282-16287, 2019.

[36] W. Guo, Q.-L. Wu, X.-J. Zhou et al., "Enhanced amoxicillin treatment using the electro-peroxone process: key factors and degradation mechanism," RSC Advances, vol. 5, no. 65, pp. 52695-52702, 2015.

[37] U. E. Osonwa, J. I. Ugochukwu, E. E. Ajaegbu, K. I. Chukwu, R. B. Azevedo, and C. O. Esimone, "Enhancement of antibacterial activity of ciprofloxacin hydrochloride by complexation with sodium cholate," Bulletin of Faculty of Pharmacy, Cairo University, vol. 55, no. 2, pp. 233-237, 2017.

[38] B. Ghimire, J. Sornsakdanuphap, Y. J. Hong, H. S. Uhm, K.-D. Weltmann, and E. H. Choi, "The effect of the gap distance between an atmospheric-pressure plasma jet nozzle and liquid surface on $\mathrm{OH}$ and N2 species concentrations," Physics of Plasmas, vol. 24, Article ID 073502, 2017.

[39] Z. B. Wang, G. X. Chen, Z. Wang, N. Ge, H. P. Li, and C. Y. Bao, "Effect of a floating electrode on an atmosphericpressure non-thermal arc discharge," Journal of Applied Physics, vol. 110, pp. 1-5, 2011.

[40] A. Eslami, F. Mehdipour, K.-Y. A. Lin, H. Sharifi Maleksari, F. Mirzaei, and F. Ghanbari, "Sono-photo activation of percarbonate for the degradation of organic dye: the effect of water matrix and identification of by-products," Journal of Water Process Engineering, vol. 33, Article ID 100998, 2020.

[41] C.-H. Kuo, L. Zhong, M. E. Zappi, and A. P. Hong, "Kinetics and mechanism of the reaction between ozone and hydrogen peroxide in aqueous solutions," The Canadian Journal of Chemical Engineering, vol. 77, no. 3, pp. 473-482, 1999.

[42] D. A. Yaseen and M. Scholz, "Treatment of synthetic textile wastewater containing dye mixtures with microcosms," Environmental Science and Pollution Research, vol. 25, no. 2, pp. 1980-1997, 2018.

[43] A. Saha, A. S. Ahammed Shabeer TP, V. T. Gajbhiye, S. Gupta, and R. Kumar, "Removal of mixed pesticides from aqueous solutions using organoclays: evaluation of equilibrium and kinetic model," Bulletin of Environmental Contamination and Toxicology, vol. 91, no. 1, pp. 111-116, 2013. 